\title{
Encountering Christ: Karl Barth and Mysticism
}

\author{
Austin Holmes \\ Boston College School of Theology and Ministry (Brighton, MA)
}

\begin{abstract}
By virtue of his insistence on the once and for all revelation of God in Jesus Christ, Karl Barth's theology has sometimes been perceived as hostile to mysticism and contemplative spirituality. Allegedly, the significance of ongoing encounters with God is lost under the weight of the proclamation of Jesus Christ as the decisive moment of God's dealing with humankind. A closer reading of Barth, however, reveals a different story. Interestingly, no serious survey of Barth's thought on mysticism exists. This paper will seek to address this gap in scholarship by briefly exploring Barth's relationship to mystical theology through engagement with his work, especially on 1) Union with God, 2) existentials of the theologians, and 3) Barth's ecstatic socialism. Contrary to the general assumptions, Barthian theology represents an undeniably rich, and modern, mystic sensibility. Aside from challenging scholarly misrepresentations of Barth, the paper raises the question of how dogmatic theology and religious experience came to treated separately in the historical development of the church and theological scholarship.
\end{abstract}

\section{Text}

Karl Barth (1886-1968) has been described as "the greatest theologian since Thomas Aquinas" by Pope Pius XII. ${ }^{1}$ He was the intellectual leader of the Confessing Church, that small portion of German Christianity that resisted Hitler and $\mathrm{Na}$ zism. Perhaps the most crucial achievement in this role was Barth's authoring of the Barmen Declaration. In the history of the modern church, Barth is identified as the voice of theological vitality that opened up the possibility for theology's future beyond Protestant Liberalism. As a respondent to the theological enterprise of Friedrich Schleiermacher, Karl Barth's thought has often been characterized as an opposition to any notion of a "religion of feeling," and nebulous "Christian experience."

${ }^{1}$ D. Stephen Long, Saving Karl Barth: Hans Urs von Balthasar's Preoccupation (Minneapolis, MN: Fortress Press, 2014), 267. 
For Karl Barth, the "good old days" of nineteenth century theology ended in the fateful year of $1914 .^{2}$ In early August, ninety-three German intellectuals signed a proclamation in support of the war policy of Wilhelm II. Barth writes, "among these intellectuals I discovered to my horror almost all of my theological teachers whom I had greatly venerated. I suddenly realized that I could no longer follow either their ethics and dogma or their understanding of the Bible and of history. For me, at least, 19th century theology no longer held any future." 3 Among the chief errors of nineteenth century theology was its willingness to ascribe normative character to the ideas of its environment. ${ }^{4}$ Nineteenth century theology had been more interested in man's relationship to God, than in God's dealings with man. ${ }^{5}$ Faith was thus reduced, having no ground, object, or content other than itself.

Theology had become a specific human self-understanding. ${ }^{6}$ "To think about God, meant to think in a scarcely veiled fashion about man." ${ }^{, 7}$ For Barth, anthropology masquerading as theology could only be a monologue, in the final analysis, our conversation with ourselves. In his awakening from nineteenth century theology's idolatrous exaltation of the human being, Karl Barth summarily stated his reaction in the sentence: "God is God." Barth's theological insistence on God's self-disclosure in Jesus Christ as the exclusive epistemological orientation of faith. ${ }^{9}$ The first theme of the Bible, Barth then realized, is God's deity, not man's religion. ${ }^{10}$ The themes of the early Barth were thus concentrated on God as "wholly other," who "breaks in upon us perpendicularly from above," and the "infinite qualitative distinction between God and man." 11 Although infrequently done, it is against this larger theological backdrop that Barth took up the matter of mysticism.

\section{Making Enemies: Karl Barth and Mysticism}

"Mysticism is esoteric Atheism." ${ }^{2}$ With stark brevity, the dutifully comprehensive Karl Barth shocks readers of volume I/2 of the Church Dogmatics,

\footnotetext{
${ }^{2}$ Karl Barth, The Humanity of God (Louisville: Westminster John Knox Press, 1960), 14.

${ }^{3}$ Barth, Humanity, 14.

${ }^{4}$ Barth, 19.

5 Barth, 24.

${ }^{6}$ Barth, 26.

${ }^{7}$ Barth, 39.

${ }^{8}$ Barth, 41.

${ }^{9}$ For an example of the ongoing importance of particularity to Barthian theology, see Stanley Hauerwas, With the Grain of the Universe (Grand Rapids, MI: Baker Academic, 2013).

${ }^{10}$ Barth, Humanity, 41.

${ }^{11}$ Barth, Humanity, 42.

${ }^{12}$ Karl Barth, Church Dogmatics, 4 vols. (New York, NY: T\&T Clark, 2009), I/2, p.322.
} 
published in 1938. ${ }^{13}$ Mysticism, for Barth, "means the basic liberation of man from that satisfaction of the religious need which hitherto he has sought outside." 14 The mystic represented the conservative counterpart to the atheist in enlightened humanity's "critical turn against religion." 15 In comparison with the loudness of atheism, Barth concluded that mysticism had generally left religion in peace: "The mystic will say the most dangerous things, e.g., about the secret identity of the within and the without, of the ego and God. But he will say them quite piously and always in connexion with a religious tradition which apparently asserts the opposite. He will, as it were, try to make the latter a witness against itself." ${ }^{\prime 6}$ Implied at the end of this description is the connection to atheism, namely that atheism and mysticism, despite their deployment of alternate vocabularies, are both ultimately parasitic on the externals of religion, dependent on the dogma each intends to subvert. Such a passage in an early volume of Barth's magnum opus supports the conclusion that his relationship with mystical theology was, at the very least, tenuous. As this is one of the few specific treatments of "mysticism" in Barth's writing, scholars often draw instead on the whole of his thought.

As the story goes, Karl Barth and mysticism were destined for conflict. One of the eminent scholars of Christian mysticism, Bernard McGinn, has written that Karl Barth "saw little good in mysticism." ${ }^{17}$ In volume I/2 of the Church Dogmatics considered above, mysticism falls on the wrong side of the ledger in Barth's diametrically opposed categories of revelation (divine work) on the one hand, and religion (human work) on the other. Indeed, this is the place of Barth's notorious subheading: "Religion as Unbelief." Scholars have implicated Barth in "perpetuating hermeneutical irresponsibility" alleging he made "very little effort to check the accuracy of his reductionist reading of contemplation." 18 More than one has also suggested that propping up Barth's dismissal of mystical theology may be Harnack's "fall-into-hellenism" thesis. If correct, this would be a rather surprising convergence between Barth and Protestant Liberalism, making them partners in an effort to blast the kerygma of Christian truth out from layers of calcified tradition and

${ }^{13}$ This would have come as a shock (in no small part) because of the admiration, even held by the cultured religious elite of the day, for Meister Eckhart who was to introduce mystical elements at the emergence of vernacular theology in Germany. This was perhaps not because of a carefully thought-out preference for the mystic, but because Eckhart held a place in German theology which would only be surpassed by the figure of Martin Luther. German theology was thus imagined inseparable from the progress of German culture. Barth's project could accurately be characterized as the attempt to separate once and for all, the revelation of God in Jesus Christ from any process of human development.

${ }^{14}$ Barth, Dogmatics, I/2, p.319.

15 Barth, 323.

${ }^{16}$ Barth, 319.

${ }^{17}$ Bernard McGinn, The Presence of God: A History of Western Christian Mysticism, vol. 1, The Foundations of Mysticism: Origins to the Fifth Century (New York, NY: Crossroad, 1991), 269. Quoted in Ashley Cocksworth, Karl Barth on Prayer (New York, NY: T\&T Clark, 2015), 29.

${ }^{18}$ Cocksworth, Barth on Prayer, 35. 
syncretism. On the contrary, Barth is notorious for his bold defense of the Christian tradition. Whether or not Barth's foundational theological commitments predisposed him to opposing mysticism is thus more complicated than presumed.

In an essay which sketches the history of the relationship between Protestantism and mysticism, Dennis Tamburello identifies nineteenth century theologian Albrecht Ritschl (1822-1889) as the thinker who distilled the preceding three centuries of Protestantism's understanding of mysticism as individualism, quietism, elitism, and, perhaps most importantly, an outgrowth of "works-righteousness" where equality exists between the mystic and God. ${ }^{19}$ In search of the reasons for the a priori Protestant dismissal of the mystic, Tamburello posits Protestant theology's emphasis of the "great distance between God and the human." ${ }^{20}$ Tamburello expresses a displeasure with this telling of the story, with which I sympathize, but his argument proceeds in terms of an unhelpful distinction between "contemplative" and "ordinary" mysticism, suggesting the magisterial reformers preferred the latter and dismissed the former. ${ }^{21}$ Another essay in the same volume by Philip Sheldrake mentions mysticism's "turn inward to the self" as a primary culprit in the Protestant-mystic divide. ${ }^{22}$ Sheldrake's essay attempts to assess the relationship of recent theology to mysticism, making use of McGinn's now famous definition of mysticism as "an immediate consciousness of the presence of God." 23 In brief, Sheldrake draws on McGinn's retelling of the history of Christian mysticism to identify the essentials as 1) reflection on the Christian sources and their application, 2) the seamless whole of the Christian life consisting of intellectual reflection and prayer, 3) Augustine's argument that God is known through sapientia rather than scientia, 4) union with God, 5) the belief that God is always other than our concepts of God, and 6) self-forgetfulness. ${ }^{24}$ Strangely, Sheldrake writes that "by concentrating on mysticism as experience, it tends to separate mysticism from theology-the ways we attempt to think or speak about God." ${ }^{25}$ Karl Rahner is heralded as the most important figure in the renewal of mystical elements in Catholic theology, and

${ }^{19}$ Dennis Tamburello, "The Protestant Reformers on Mysticism” in The Wiley-Blackwell Companion to Christian Mysticism, ed. Julia Lamm (West Sussex, UK: Blackwell Publishing, 2013), 407.

${ }^{20}$ Tamburello, "Reformers on Mysticism," 409.

${ }^{21}$ Tamburello, 409-419. As part of his discussion of Luther and Calvin, Tamburello intends to distinguish between the exotic and the germane, leading to a rather unfortunate enlistment of "contemplation."

22 Philip Sheldrake, "A Critical Theological Perspective," in The Wiley-Blackwell Companion to Christian Mysticism, ed. Julia Lamm (West Sussex, UK: Blackwell Publishing, 2013), 353. Presumably Sheldrake means to implicate a general Protestant skepticism with regards to the inner-person and the conscience, but this is not entirely clear.

${ }^{23}$ McGinn, Foundations of, p.xix. Quoted in Sheldrake, "Theological Perspective," 533.

${ }^{24}$ Sheldrake, 535-538.

${ }^{25}$ Sheldrake, 533. Sheldrake cites Michel de Certeau's (1925-1986) work as an example of scholarship on mysticism as distinct from theology. 
Sheldrake includes the often quoted dictum "Christians of the future will be mystics or nothing at all." 26 The very next paragraph begins "Karl Barth, by contrast..." We learn Barth was concerned that mysticism was too preoccupied with experience and affectivity, the emotional. ${ }^{27}$ In brief, Barth's theology is irreconcilable with mysticism's exaltation of the human being. However, what Sheldrake proposed as unpalatable to Barth is only the misconceived mysticism which McGinn and others have sought to rewrite. Such an opposition between Barth and mysticism perpetuates a false description. This means there is need to retrieve the latent mystical elements of Barth's theology, which we might call the task of recognizing the recognition of God's presence in Barth. I wish to challenge the prevailing narrative by drawing attention to three areas of Karl Barth's thought: 1) "Union with Christ" as a description of the most basic reality of all human existence, 2) what Barth called the "existentials of the theologian," and 3) Barth's socialist political activism as a manifestation of the common mystical theme of ekstasis.

\section{Union with Christ}

In 1921, Karl Barth accepted a professorship in theology at Göttingen, and began a series of lectures through the New Testament. The most consequential work from this period is undoubtedly Der Römerbrief (Commentary on Romans) in which Barth presented Christian truth in terms diametrically opposed to that of his Liberal Protestant teachers. Recently, the lectures on Ephesians have been translated into English for the first time. ${ }^{28}$ They reveal a young Barth who had come to see the heart of Christianity as the existential reality of God's confronting the human creature. This encounter formed the basis of Paul's gospel. One preeminent theme of these lectures, which would become a cornerstone in Barth's later theology, was the Greek phrase "en Christo" ( $\dot{v} v$ X utterly disturbing revelation of the human creature's true situation. ${ }^{29}$ Barth writes of the infinite distinction between God and the creature as also precisely being the basis of their unity: "God can bless man only as his creature; man can bless God only as his creator." 30 This relationship is the most basic description of reality that can be offered. Barth writes:

${ }^{26}$ Karl Rahner, Theological Investigations XX (New York, NY: Crossroad, 1991), 149. Quoted in Sheldrake, 541.

${ }^{27}$ Rahner, 541.

${ }^{28}$ Karl Barth, The Epistle to the Ephesians, ed. David Nelson, tr. Ross Wright (Grand Rapids, MI: Baker Academic, 2017).

29 "What is expressed by [en Christo] is not a general, universal truth and therefore cannot be expressed directly--either rationally or irrationally, speculatively or experientially through the vagaries of the 'pious consciousness.' Rather, it is expressed existentially, indirectly from God and by God." Barth, Ephesians, 82.

${ }^{30}$ Barth, 83 . 
being en Christo is the presupposition and goal of our human being, having, and doing--the beneplacitum Dei on the one hand and the glorificatio Dei on the other--in their original relation, not the human creature's existence or anything he might produce or achieve. Paul would never have described his conversion at Damascus as the cause of his being in en Christo. He was not en Christo because he experienced Damascus; rather, he experienced Damascus because he was en Christo. ${ }^{31}$

By designating en Christo as the ontological presupposition of humankind, not merely one possibility among others, Barth prefigures his doctrine of election, in which the choice of the one human, Jesus Christ, is God's reaffirmation of his choice of the whole of humanity at creation. ${ }^{32}$ That is, there is no strong distinction in Barth's theology between the acts of creation and redemption; there is just the one God's eternal determination to be the God of humankind.

Characteristically, Barth's discussion of the concept of our "union with God" in the Church Dogmatics begins with the decisive divine act in Jesus Christ, before proceeding to the role of the Christian. By the time of the Barth's work on Volume IV/3, there is also an emerging deeper appreciation of the reciprocal "human" element. Since the biblical witness presupposes Christ in us, the textual emphasis is on us in him. ${ }^{33}$ While union with God is undoubtedly initiated from above downwards, it involves a subsequent movement from below upwards. Union between God and the one whom he calls describes a real totality, but also a real partnership in which neither of the two primordial actors are lost. In this union, Christ gives himself, causing his own life to be that of the Christian. ${ }^{34}$ This grace, far from suppressing the human response, engages the "miracle of our involvement." 35 Though this union remains incomprehensible, Barth does not shy away from the Christian's awareness. "If there is any action which is well grounded and assured in respect of its goal, it is the faith, obedience, and confession of the Christian." ${ }^{\prime 36}$

\section{Existentials of the Theologian}

In 1960, Karl Barth made his way to the United States for a series of lectures on the nature of the work of theology. Three years later these lectures would appear

\footnotetext{
${ }^{31}$ Barth, 83.

${ }^{32}$ A thoroughgoing analysis of the way in which Barth's early scriptural-metaphysics determined his later doctrinal development remains an enticing project.

${ }^{33}$ Karl Barth, Church Dogmatics, 4 vols. (New York, NY: T\&T Clark, 2009), IV/3, p.546.

${ }^{34}$ Barth, Dogmatics, IV/3, p.540.

${ }^{35}$ Barth, 541.

${ }^{36}$ Barth, 546.
} 
in published form in Evangelical Theology: An Introduction. It represents a remarkable distillation of Barth's self-understanding as a theologian. Barth presents a fourfold foundation that makes theology possible. These Barthian premises, in contrast to an innate religious capacity, are the particulars of "The Word, The Witness, The Community, and The Spirit." ${ }^{37}$ In part two, Barth turns to address "existentials of the theologian."

Wonder is the first and most constitutive description of the theologian's existence. This is the quite specific astonishment that stands at the beginning of every theological thought. ${ }^{38}$ Wonder occurs in a strange encounter, unable to be assigned a place in the previous circle of our ideas of what is possible. Barth seems uncharacteristically hard-pressed for descriptions at this juncture. This wonder is like an uncontrolled control over us. "If a man could domesticate this wonder, he would not yet have taken the step into theology." ${ }^{39}$ Wonder, as encounter, is a gift of the Holy Spirit in which the biblical witness sounds like an alarm and generates hope. As an example of how this works, Barth describes our astonishment at the miracles in the gospels:

To what do the following phrases point? "Rise, take up your bed and go home." "Come out of the man, you unclean spirit!" "Peace, be still!" as was called out to a stormy sea. "You, give them to eat!" "Lazarus, come out!" "He has risen, he is not here." What took place were promises and intimations, anticipations of a redeemed nature, of a state of freedom, of a kind of life in which there will be no more sorrow, tears, and crying, where death as the last enemy will be no more. This kindling of the light of hope is what is really new, it is the really surprising element in the biblical stories. ${ }^{40}$

Theology is always initiated by an event, an encounter, in which God confronts us. For Barth, God is the object of theology as the object of apostolic testimony, but the God who is the object of apostolic testimony has determined also to be its speaking subject:

This object disturbs...It invaded, surprised, and captured him. It assumed control over him. Before he knows anything at all, he finds himself known and consequently aroused and summoned to knowledge. He finds himself

${ }^{37}$ Karl Barth, Evangelical Theology: An Introduction, tr. Grover Foley (New York: Holt, Rinehart, and Wilson, 1963). See especially pp.15-62.

${ }^{38}$ Barth, Evangelical Theology, 64.

${ }^{39}$ Barth, 65.

${ }^{40}$ Barth, 68-69. 
freed to be concerned with this object long before he can even reflect on the fact that there is such a freedom. ${ }^{41}$

This wonder has its genesis in the event of faith, the conditio sine qua non of the work of theology. Barth's application of "event" to faith frees us from the premonition that faith is ever either our creation or possession. Faith ought never to replace the object of theology, otherwise it would become, as it did in the 19th century, "pisteology." ${ }^{42}$ For Barth, "faith is a history, new every morning. It is no state or attribute. It should not be confused with mere capacity or willingness to believe." 43 We will only ever say "I believe" with the entreaty "Lord help my unbelief." We ought never to suppose we have faith, but we will "hope and hope and hope for it as the Israelites hoped afresh every morning for manna in the wilderness." 44

The oddity of alienating Barth and mysticism is nowhere more obvious than in his reflections on the necessity of prayer to the work of theology. "Where theology is concerned, the rule ora et labora is valid under all circumstances--pray and work!" 45 Barth insists:

Proper and useful theological work is distinguished by the fact that it takes place in a realm which not only has open windows, facing the surrounding life of the Church and the world, but also and above all has a skylight. That is to say, theological work is opened by heaven and God's work and word, but it is also open toward heaven. ${ }^{46}$

Should any attempt be made to proceed apart from this vertical openness, "what theologian is there who is not continually surprised to find...that he is moving about in a human, all too human, circle...like a squirrel in a cage?"47 The theologian who exists alone is not a theologian at all. ${ }^{48}$ All human thought and speech in relation to God can only have the character of a response to be made to God's Word:

The task of theological work consists in listening to Him, this One who speaks. The Word of this One is no neutral announcement, but rather the critical moment of history and the communion between God and man. This word is God's address to men. "I am the Lord your God, who led you out

\footnotetext{
${ }^{41}$ Barth, 76.

42 Barth, 99.

${ }^{43}$ Barth, 103.

${ }^{44}$ Barth, 105.

${ }^{45}$ Barth, 160.

${ }^{46}$ Barth, 161.

${ }^{47}$ Barth, 161.

${ }^{48}$ Barth, 162.
} 
of the land of Egypt, out of the house of bondage. You shall have no other gods before me." Human thought and speech cannot be about God, but must be directed toward God, called into action by the divine thought and speech...What is essential for human language is to speak of men in the first person and of God in the second person...And this means that theological work must really and truly take place in the form of a liturgical act, as invocation of God, and as prayer. ${ }^{49}$

Barth's insistence on prayer, an extension of his insistence on the event of divinehuman encounter, invites exactly the sort of subversion of established theology with which mysticism has been identified. That is, subversion not for the sake of subversion, but subversion for the sake of renewal, the logical conclusion of a God who is always other than our concepts of God:

Theological work is distinguished from other kinds of work by the fact that anyone who desires to do this work cannot proceed by building with complete confidence on the foundation of questions that are already settled, results that are already achieved, or conclusions that are already arrived at. He cannot continue to build today in any way on foundations that were laid yesterday by himself, and he cannot live today in any way on the interest from a capital amassed yesterday. His only possible procedure every day, in fact every hour, is to begin anew at the beginning. And in this respect theological work can be exemplary for all intellectual work. Yesterday's memories can be comforting and encouraging for such work only if they are identical with the recollection that this work even yesterday had to begin at the beginning and, it is to be hoped, actually began there. The ever-new start is the only possible way because the object of theology is the living God himself in his free grace, Israel's protector who neither slumbers nor sleeps. ${ }^{50}$

\section{Barth's Ecstatic Socialism}

One often overlooked aspect of Barth's theology bears interesting implications for my argument that Barth's relationship with mysticism be viewed more positively. That is, his lifelong activism and commitment to leftist socialist politics. As a young pastor in Safenwil, Barth often preached sermons related to workers'

\footnotetext{
${ }^{49}$ Barth, 164.

${ }^{50}$ Barth, 165-66.
} 
rights, labor reform, and the evil of capitalism. ${ }^{51}$ Barth's reputation as a socialist even garnered him the nickname "the red pastor." An early essay of Barth's entitled "Jesus and the Movement for Social Justice" was delivered before a local labor union in 1911 and has recently been translated into English. In that presentation, which would garner the attention of several local papers, Barth wrote,

What Jesus has to bring to us are not ideas, but a way of life. One can have Christian ideas about God and the world, or about man and his redemption, and still with all that be a complete heathen. And as an atheist, a materialist, and a Darwinist, one can be a genuine follower and disciple of Jesus. Jesus is not the Christian worldview and the Christian worldview is not Jesus. ${ }^{52}$

Barth is every bit the controversialist at this early stage in his life as he would be later in life as the veteran theologian. Listeners were privileged to such lines as:

The spirit that has value before God is the social spirit. And social help is the way to eternal life. ${ }^{53}$

Jesus is more socialist than the socialists. ${ }^{54}$

For Jesus, there was only a social God, a God of solidarity; therefore there was also only a social religion, a religion of solidarity. ${ }^{55}$

Real socialism is real Christianity in our time. ${ }^{56}$

One of mysticism's key elements identified in the essay by Sheldrake is that of selfforgetfulness. For Karl Barth, socialist politics represented the continued embodiment of Jesus' humanism. If ecstasy, as suggested by this journal's theme, is "any moment in which we are drawn outside ourselves and encounter the other," the Barthian way to proceed involves exploring the vital connection between theology and radical politics. At the heart of God is the cross, and so mystical union leads to an ever deeper identification with the person of Jesus Christ. This union must not

${ }^{51}$ The inseparability of Barth's politics from his theology is little known to non-specialists, but George Hunsinger's recent volume offers an excellent introduction: George Hunsinger, Karl Barth and Radical Politics (Eugene, OR: Wipf and Stock, 2017). Politics, 4.

${ }^{52}$ Karl Barth, "Jesus and the Movement for Social Justice" in Hunsinger, Radical

${ }^{53}$ Karl Barth, "Social Justice," 8.

${ }^{54}$ Barth, 10.

${ }^{55}$ Barth, 13.

${ }^{56}$ Barth, 15. 
itself become an end. Instead, it is to represent again and again a new point of departure where we return to our existence in the world, to unity with our neighbor, to the self-giving love of the cross. For Barth, the icon of mysticism becomes the political martyr, and here one cannot help but think of his disciple Dietrich Bonhoeffer's death as a prisoner of the Nazis.

\section{Conclusion}

These theological elements point towards a Barth dependent on genuine experience, the event of God's encounter with him. Barth exemplifies the Augustinian preference for sapientia over scientia, of assurance over comprehension. His discourse on wonder and prayer are part of a vision for the seamless whole of theological existence. At the very heart of the Church Dogmatics lies a doctrine of God's union with humankind. If Rahner and Vorgrimler are correct that mysticism is "not a denial of the world, but a taking of the world with one to a loving encounter with the personal God," we are likely not to find a better recent example than in the radical politics of Karl Barth. ${ }^{57}$

In 1960, reflecting on the disruptive theology of his youth, Barth confessed that it had at times been an overreaction. Barth never lost sight of the importance of the "infinite qualitative distinction" between God and us, but in his later years would write:

God's otherness is known only in his togetherness with man...Who God is and what he is in his deity he proves and reveals not in a vacuum as a divine being-for-himself, but precisely and authentically in the fact that he exists, speaks, and acts as the partner of man...He who does that is the living God. And the freedom with which he does that is his deity. ${ }^{58}$

In other terms, God's deity includes his humanity, because in Jesus Christ there is no isolation of humankind from God or God from humankind. His freedom to be in and for himself, his god-ness, is his determination to be with and for us in the history of the Gospel.

The lingering questions raised by this paper are therefore: what happened in the course of the church's history to relegate mysticism to the realm of the exotic? What happened to make intelligible the distinction between Barth's dogmatic theology and the mysticism upon which all theology, including Barth's, surely depends? How is it that "mystical" came to be viewed as a further qualification of

${ }^{57}$ See entry "mysticism” in Karl Rahner, Herbert Vorgrimler, Concise Theological Dictionary (London, UK: Burns \& Oates, 1965).

${ }^{58}$ Barth, Humanity, 45. 
theology? Christian, it would seem, is quite enough. These questions remain open. Were there more time, we might turn to more fully consider the sociological explanations for why a mystic emerges at all. Friedrich von Hügel wrote that the mystic inevitably emerges as the voice of the spontaneous-emotional dynamic of religion in a context where it has been suffocated by the institutional-dogmatic element. Such an explanatory framework cannot adequately account for the event that was Karl Barth. As it is, von Hügel's explanation precludes the possibility of the nineteenth century's theological moment, when it was precisely the spontaneous-emotional dynamic of Schleiermachean "feeling" that became the reigning institutional dogma. Karl Barth represented a new embodiment of the characteristically mystical enterprise of theological subversion. However, this was taken up with renewed vigor for the production of dogmatic theology, rather than its erasure. His theology appealed to the particularities of God's revelation in Jesus Christ, and this was the most profound way to state God's otherness in the context of the nineteenth century's wake. For his embodiment of dogmatic rigor and religious experience, perhaps Karl Barth belongs among the names of scholastic mystics such as Anselm, Aquinas and Bonaventure. It is within this larger catholic tradition, with a rare sermonic and symphonic pen, that Barth's dogmatic theology continues to draw Christians into encounters with the God who makes himself known in Christ.

\section{Bibliography}

Barth, Karl. Church Dogmatics. 4 vols. Edited by G.W. Bromily and T.F. Torrance. Translated by G.W. Bromily, G.T. Thomson, and Harold Knight. New York, NY: T\&T Clark, 2009.

—. Evangelical Theology: An Introduction. Translated by Grover Foley. New York, NY: Holt, Rinehart, and Wilson, 1963.

—. "Jesus Christ and the Movement for Social Justice" (1911). In Karl Barth and Radical Politics, edited by George Hunsinger. Eugene, OR: Cascade Books, 2017.

- The Epistle to the Ephesians. Edited by David Nelson. Translated by Ross Wright. Grand Rapids, MI: Baker Academic, 2017.

\footnotetext{
- The Humanity of God. Louisville, KY: Westminster John Knox Press, 1960.
}

Cocksworth, Ashley. Karl Barth on Prayer. New York, NY: T\&T Clark, 2015. 


\section{HOLMES: BARTH AND MYSTICISM}

Hunsinger, George. Karl Barth and Radical Politics. Eugene, OR: Cascade Books, 2017.

Lamm, Julia, ed. The Wiley-Blackwell Companion to Christian Mysticism. West Sussex, UK: Blackwell Publishing Ltd, 2013.

Long, Stephen D. Saving Karl Barth: Hans Urs von Balthasar's Preoccupation. Minneapolis, MN: Fortress Press, 2014.

McGinn, Bernard. The Foundations of Mysticism. 7 vols. New York, NY: The Crossroad Publishing Company, 2002.

Sheldrake, Philip. “A Critical Theological Perspective.” In The Wiley-Blackwell Companion to Christian Mysticism, edited by Julia Lamm. West Sussex, UK: Blackwell Publishing, 2013: 533-549.

Tamburello, Dennis. "The Protestant Reformers on Mysticism.” In The WileyBlackwell Companion to Christian Mysticism, edited by Julia Lamm. West Sussex, UK: Blackwell Publishing, 2013: 407-421. 